\title{
FACTORS DETERMINING THE DECISION OF FARMERS TO IMPROVE QUALITY OF COFFEE PRODUCTION AND CHANGES OF EARNED INCOME IN THE SEMENDE DARAT LAUT DISTRICT, INDONESIA
}

\author{
Amanda Aulia*, Mulyana Andy, Aryani Desi \\ Masters Program in Agribusiness, Faculty of Agriculture, University of Sriwijaya, Indonesia \\ *E-mail: aulia.amanda67@yahoo.com
}

\begin{abstract}
This research was conducted in the Semende Darat Laut District of South Sumatra Province. The location selection was done intentionally (purposive).With consideration that the district is coffee production center and the majority of the population are coffee farmers. The method used in this study was a survey method. This method was carried out directly to the location of the study and conducted interviews with respondents. Then a sample of farmers who made efforts to improve the quality of coffee production was taken and also those who did not. From the total number of farmers, the data for the number of sample farmers was 80 people. The results of this study indicated that there were factors determining farmer decisions in an effort to improve the quality of coffee production namely land area, farmer age, other agricultural income, coffee prices, farm time, and labor costs.
\end{abstract}

\section{KEY WORDS}

Farmers, production, quality, coffee, income, good agriculture practice.

Potential development of coffee plantation is needed to support increased productivity and agricultural inputs that are still low (FAO, 2004; GTZ, 2000). Based on that statement, the good quality coffee beans will influence the sale price at the farmers level (Akiyama et al., 2005).

Various efforts are needed to get good quality coffee beans. Therefore farmers must pay attention to conditions of geographical location such as places, soil, varieties of coffee and so on. Then, pay attention to cultivation technique such as maintenance, pruning routine, pests and diseases control, fertilizing, and the harvesting process. The quality of coffee beans is determined from the post-harvest process that starts from the processing of coffee beans based on the Indonesian National Standard (SNI) (Subagyo, 2000).

Coffee production quality rating system generally refers to several criteria based on the Indonesian National Standard (SNI), including origin, ecosystem, variety, and how to harvest, how to process, size of seeds, defect value, and taste. The general quality requirements for coffee beans are that there are no living insects, no foul-smelling and mold-smelling beans, a maximum water content of 12.5 percent, and non-coffee dung of 0.5 percent (Joko, 2018).

South Sumatra Province has a great opportunity in terms of developing coffee commodities. It's because that region has production factors, one of which is vast land with the potential of high amount production in the cultivation of coffee commodity compared to other provinces (Widiarti, 2008).

According to Junaidi (2010), South Sumatra Province is a potentially high factual area for the development of Robusta coffee, because most of them cultivate Robusta coffee as a leading commodity. If this potential can be developed properly, then the income of farmers can grow through efforts of improving the quality and quantity of coffee production.

Based on Agricultural Data and Information of the Ministry of Agriculture (2017), the highest coffee production of independent plantations is from South Sumatra province. With average production of 110,481 tons with total area of 250,172 ha and the second highest is Lampung province with average production of 110,368 tons of coffee annually and a land area of 162,020 ha.

Based on information from the Head of Marketing in the Agricultural Agency Office in Muara Enim Regency (2019), the problems often faced by coffee farmers are: Some farmers 
have not realized the importance of increasing productivity through improving the quality of coffee production because of constraints with capital, and knowledge; Farmers are more concerned with quantity rather than the quality of coffee production; There are controls in determining the price and distribution of coffee beans resulting in the loss of identity of coffee origin because it is claimed by other coffee producing regions. The existence of traditions carried on from generation to generation is detrimental not only to farmers but also consumers.

The district which is the center of coffee production in Muara Enim Regency and has the potential to develop a coffee plantation system based on the highest amount of coffee production is Semende Darat Laut District with a production of 11,485 tons. Meanwhile, the area of productive plantations is 10,503 ha. Based on those production data, then the Semende Darat Laut District has enough potential to increase coffee production compared to other districts. Based on information from the Agricultural Agency Office of Muara Enim Regency (2019), that the Semende Darat Laut District has formed a special farmer groups for coffee plantation and also made efforts to match the time of harvesting. Based on explanation above, the researchers chose the Semende Darat Laut District to become the location of the study.

From conditions mentioned above, researchers were interested in examining the decision of farmers in making efforts to improve the quality of coffee production to increase their farm revenue in the Semende Darat Laut District. With the objective of farmers in other regions to adopt and implement it like the farmers in the Semende Darat Laut District. Therefore to be a reference for coffee farmers and the government of other regions in the South Sumatra Province to help increase the income of coffee farmers.

\section{LITERATURE REVIEW}

In efforts to improve the quality of the coffee production, the farmer should pay attention to the system of agriculture that can be refer to proper coffee cultivation in accordance with the guidelines of Good Agriculture Practice (GAP), which are: land preparation, seedling, planting, maintenance (pruning, fertilization, pest and disease control), harvest and post-harvest. (Ministry of Agriculture Directorate General of Plantations, 2014).

Those mentioned above can influence the quality and quantity of coffee production so that it can increase the revenue of the coffee plantation. The standard of quality of the coffee beans generally based on the Standard National Indonesia (SNI) and Standard Specialty Coffee Association of America (SCAA) which are the coffee must have low level of water content, coffee beans that is not deformed or damaged, the uniformity of the color, the fresh smell, and the uniformity of the size of the beans.

Based on Nita's research (2014), it is known that the factors that have a positive influence on farmers' decisions to improve the quality of coffee production were revenue from coffee plantation and participation in certification. Meanwhile, other variables like a vast land, education, the agriculture experience, and the number farmers' family members did not have significant influence.

\section{METHODS OF RESEARCH}

The sample research method used in this study was a sampling technique if the population is stratified but proportionate (proportionate stratified random sampling), in determining the sample, the researcher chose representatives from each group in the population whose numbers are adjusted to the number of subjects in the population in each of these groups. Then a sample of farmers who made efforts to improve the quality of coffee production was chosen along with those who did not made efforts. From the total number of farmers, the number of sample farmers was 80 people. The following was the number of farmers chosen based on the farmers who made efforts to improve the quality of coffee production was 40 farmers and 40 farmers who did not made the efforts. 
The method used in this study was survey method. This method was carried out directly in the location of the study and conducted by interviewing the respondents. This method was done by choosing a sample of the population in the Semende Darat Laut District. The use of this method was intended to carry out comprehensive observations to obtain the facts of the phenomenon that exist and look for actual information from the sample in the area under study.

To find out the determining factors for farmers to undertake efforts to improvement of the quality of the coffee production, the analysis Logistics Binary (binary logistic regression) was used. To analyze it can be in formulated into the equation as follows (Winarno, 2007):

$$
\mathrm{Y}=\operatorname{Ln} \frac{P_{i}}{1-P_{i}}=\left(\beta_{0}+\beta_{1} \mathrm{x}_{1}+\beta_{2} \mathrm{x}_{2}+\beta_{3} \mathrm{x}_{3}+\beta_{4} \mathrm{x}_{4}+\beta_{5} \mathrm{x}_{5}+\beta_{6} \mathrm{x}_{6}+\beta_{7} \mathrm{x}_{7+} \beta_{8} \mathrm{x}_{8 . \cdots . .)}\right)
$$

Where:

$\mathrm{P}=$ Opportunity for farmers to make efforts to improve the quality of coffee production;

$Y=1$ = farmer's decision to make efforts to improve the quality of coffee production;

$0=$ farmer's decision not to make efforts to improve the quality of coffee production;

$\mathrm{X}_{1}=$ Land Area (ha);

$\mathrm{X}_{2}=$ Farmer's Age (th);

$\mathrm{X}_{3}=$ Age of Coffee Plants (th);

$\mathrm{X}_{4}=$ Other Agricultural Income $(\mathrm{Rp} / \mathrm{yr})$;

$\mathrm{X}_{5}=$ Coffee Plantation Income $(\mathrm{Rp} / \mathrm{yr})$;

$\mathrm{X}_{6}=$ Selling Price of Coffee Beans Based on Quality (Rp / th);

$\mathrm{X}_{7}=$ Distance to farm location's production costs $(\mathrm{Rp} / \mathrm{yr})$;

$\mathrm{X}_{8}=$ Duration of farming (Th);

$\mathrm{X}_{9}=$ Labor Costs $(\mathrm{Rp} / \mathrm{yr})$;

$\mathrm{B}_{0}=$ Constant.

Some test criteria that must be met to assess the overall fit of the model against the data are as follows.

-2 log likelihood statistics:

Used to determine whether the addition of independent variables into the model are significantly improving the model. Can be seen when the decrease in value of $-2 \log$ likelihood of block 0 to block 1.

The feasibility of the model by looking at the value of the Hosmer and Lemeshow Test with a hypothesis:

$\mathrm{HO}$ : There is not any difference between farmers who made efforts to improve the quality of the coffee production to farmers who did not;

$\mathrm{Ha}$ : There are differences between farmers who made efforts to improve the quality of the coffee production to farmers who did not.

Decision making criteria:

- If significant $>(\alpha=0.05)$, it means that there is no difference between farmers who made efforts to improve the quality of the coffee production to farmers who did not;

- If significant $<(\alpha=0.05)$ which means that there are differences between farmers who made efforts to improve the quality of the coffee production to farmers who did not.

$$
\mathrm{G}=-2 \frac{\text { likeli hood tanpa peuba } h \text { bebas }}{\text { likeli hood dengan peuba } h \text { bebas }}
$$

G Test is used to examine the role of variable descriptors in the model together with the formulation as follows:

$$
\mathrm{H}_{0:} \beta_{1}=\beta_{2}=\beta_{3}=\beta_{4}=\beta_{5}=\beta_{6}=\beta_{7}=\beta_{8}=0
$$

$H_{1 \text { : }}$ There is at least one $\beta$ that is not equal to 0 
Wald test used to determine the role of each independent variables to the dependent variable with the hypothesis as follows:

Ho: independent variables did not influence significantly to the farmers' decision to make efforts to improve the quality of the coffee production;

$\mathrm{Ha}$ : independent variables influence significantly to the farmers' decision to make efforts to improve the quality of the coffee production.

\section{RESULTS AND DISCUSSION}

Factors that determine farmers' decisions in making efforts to improve the quality of coffee production were 9 variables. To find out how much the value of the farmers' decision to make improvements in the quality of coffee production in the Semende Darat Laut District, the Logistics Binary analysis (binary logistic regression) was used with the help of software SPSS 16.0 and can be seen in Table 1.

Table 1 - The results of the alleged parameters of several variables that influence farmers' decisions in making efforts to improve the quality of coffee production

\begin{tabular}{lllll}
\hline No & Variables & Coefficient value $(\mathrm{B})$ & Significant & Note \\
\hline 1 & Land Area $\left(\mathrm{x}_{1}\right)$ & 2,485 & 0.023 & $\mathrm{~A}$ \\
2 & Farmer's Age $\left(\mathrm{x}_{2}\right)$ & 2,635 & 0.024 & $\mathrm{~A}$ \\
3 & Age of coffee plant $\left(\mathrm{x}_{3}\right)$ & $-1,625$ & 0.329 & - \\
4 & Other Agricultural Income $\left(\mathrm{x}_{4}\right)$ & $-1,828$ & 0.044 & $\mathrm{~A}$ \\
5 & Coffee Plantation Income $\left(\mathrm{x}_{5}\right)$ & 1,319 & 0.436 & - \\
6 & Coffee Price $\left(\mathrm{x}_{6}\right)$ & 3,776 & 0.087 & $\mathrm{~B}$ \\
7 & Distance of farm location $\left(\mathrm{x}_{7}\right)$ & $-0,201$ & 0.749 & - \\
8 & Duration of farming $\left(\mathrm{x}_{8}\right)$ & 3,436 & 0.014 & $\mathrm{~A}$ \\
9 & Labor costs $\left(\mathrm{x}_{9}\right)$ & 43,020 & 0.018 & $\mathrm{~A}$ \\
10 & Constants & $-111,906$ & 0.024 & $\mathrm{~A}$ \\
\hline
\end{tabular}

Note: $A$ = Significant at $5 \%, B=$ Significant at $15 \%, G^{2}=96 \%, R^{2}=93.4 \%$.

Based on Table 4.21 the following equation model can be formulated:

(odds) $=\mathrm{e}^{-111,906+2,485(X 1)+2,635(X 2)-1,625(X 3)-1,828(X 4)+1,319(X 5)+3,776(X 6)-0,201(X 7)+3,436(X 8)+3,436(X 4)+1,319(X 5)+3,776(X 6)-0,201}$ $(X 7)+3,436(X 8)+3,436(X 4)+1,319(X 5)+3,776(X 6)-0,201(X 7)+3,436(X 8)+3,436(X 4) X 9)$

The results of the binary logistic regression analysis in Table 1, are economically sign and value with each independent variable according to economic theory. Factors that influence the decision of farmers in making efforts to improve coffee production consisting of variables Land Area, Farmer's Age marked negative, Age of Coffee Plants marked negative, Other Agricultural Income marked negative, Coffee Plantation Income marked negative, Coffee Price, Distance of Farm Location marked negative, Duration of Farming, and Labor Costs. Explanation of the factors that influence farmers' decisions in making efforts to improve the quality of coffee production can be explained in detail as follows:

To find out the motives of the farmers' decision to improve coffee production, binary logistic regression analysis was used in this study, there were several variables that allegedly influenced farmers' decisions. So based on Table 1, to find out whether there was significant influence or not between the land area with the farmers' decision in trying to improve the quality of coffee production, it was found that a significant test of land area variable with a value of 0.023 which means the variable has a significant influence on the level $\alpha$ of 0,05 . Because the significant value was smaller than the alpha value, thus the $\mathrm{HO}$ was rejected, which means the land area had a significant influence on the decision of farmers in making efforts to improve the quality of coffee production. Because the coefficient value was positive, it can be interpreted that the bigger the land area, the more likely the farmer will improve the quality of coffee production.

One of the factors that determine farmers' decisions in making efforts to improve the quality of the coffee production is the farmer's age. Based on Table.1, the farmer's age has a 
positive coefficient value of 2.635, if the significance of its influence ignored, this value can be interpreted that the higher the farmer's age, the greater the possibility of farmers making efforts to improve the quality of coffee production. To find out if there is significant influence or not between the farmer's age and the decision of farmers in trying to improve the quality of coffee production, it was found from significant test of farmer's age variable with a value of 0.024 which means that the variable has a significant influence on the level $\alpha$ of 0.05 .

Because the significant value is smaller than the alpha value thus the $\mathrm{HO}$ is decline, which means the age of farmers has a significant influence on the decision of farmers to make efforts to improve the quality of coffee production. Because the coefficient value is positive, it can be interpreted that the higher the farmer's age, the more likely the farmer will improve the quality of coffee production. The sample of farmer's age based on farmers who make efforts to improve the quality of coffee production and those who did not try to improve, there were various ages of farmers from 80 farmers sample with the average age of 20-40 years old and over.

Based on Table 1, the coefficient value of other agricultural income is negative (1.828). A significant test of other agricultural income variable was carried out with a value of 0.044 , and has a significant influence on the $\alpha$ value of 5 percent. Meaning, the test value was significantly smaller than the alpha value so $\mathrm{H} 0$ was rejected. Thus it can be interpreted that the other agricultural income significantly influences farmers' decisions in making efforts to improve coffee production.

It can be interpreted that the higher the other agricultural income, the lesser the possibility of farmers' decision in trying to improve the quality of coffee production, this because farmers who have high income from other agriculture crop generally more focused on other agriculture crop rather than the coffee plantation. So the coffee plant is only a side farm because the production is smaller than other farms.

To find out whether or not the influence of coffee price variable on farmers' decisions in making efforts to improve the quality of coffee production was tested by using logistic regression. Based on Table 1, the value of the coefficient of coffee prices is positive (3.776). Then a significant coffee price variable test was performed with a value of 0.087 , it had a significant influence of $\alpha 15$ percent. It found out that the test value was significantly smaller than the alpha value thus $\mathrm{H} 0$ was rejected. It can be interpreted that the price of coffee has a significant influence on the decisions of farmers in making efforts to improve coffee production.

Based on the positive value of the coefficient, it can be interpreted that the higher the price of coffee, the chance of farmers' decisions in making efforts to improve the quality of coffee production was further increased, it was because farmers who sell coffee beans in accordance with their quality influenced the price of the coffee beans which also getting higher.

The average price of coffee beans in Semende Darat Laut District was around Rp.18,000-25,000 per kilogram. The difference in coffee prices was because there were differences in the quality of coffee beans or coffee grains. The majority of coffee farmers in the district sells their coffee to middlemen or toke.

Based on Table 1, the coefficient of duration of coffee plantation variable value is positive $(3,436)$. Then a significant test of duration of coffee plantation variable was tested with a value of 0.014 , so that the significant influence was $\alpha 5$ percent. This means, the test value was significantly smaller than the alpha value so $\mathrm{HO}$ was rejected. It can be interpreted that the duration of coffee plantation significantly influenced farmers' decisions in making efforts to improve coffee production.

Based on the positive coefficient value, it can be interpreted that the longer the duration of coffee plantation, the greater the possibility of farmers' decision to make efforts to improve the quality of coffee production, it is because farmers who have longer agricultural experience, the higher their awareness of trying to improve the quality of coffee production including a more intensive maintenance until the post-harvest process.

Based on Table 1, the value of the coefficient of labor costs is positive (43.020). Then a significant test of labor costs variable was carried out with a value of 0.018 , so that it has a 
significant influence on the value of $\alpha$ of 5 percent. This means, the test value was significantly smaller than the alpha value so $\mathrm{HO}$ was rejected. Thus, it can be interpreted that labor costs significantly influence farmers' decisions in making efforts to improve coffee production. Based on the positive value of the coefficient, it can be concluded that the higher the labor costs, the further the increase of the likelihood of farmers' decisions in making efforts to improve the quality of coffee production.

\section{CONCLUSION AND SUGGESTIONS}

Based on the analysis of the research results, conclusions and suggestions can be drawn of which there are factors that influence farmers' decisions in efforts to improve the quality of coffee production, namely land area, farmer's age, other agricultural income, coffee prices, duration of farming, and labor costs.

It is recommended that coffee farmers who have not made efforts to improve the quality of coffee production should make these efforts by improving the agricultural stages to the process of post-harvesting according to GAP guidelines, because according to the results of this study, it was found out that by making these efforts farmers get higher incomes compared to farmers who do not make an effort.

It is recommended for coffee farmers who have sought to improve the quality of coffee production, in addition to selling red-picked coffee beans to IndoCapco Company, to increase revenue, farmers and farmer groups should make a small and medium-sized business to sell coffee grounds and food products from coffee ingredients originated from Semende Darat Laut District. Thus, it becomes an added value for farmers in the area. It is recommended for local governments with the potential of coffee plantation should paid more attention to its development, by forming a team to routine surveys of the farmer groups.

By forming groups of small and medium-sized businesses by means of a business capital loan and fostered to become a farmer in the area. So that coffee farmers are eager to make more efforts to improve the quality of coffee production in terms of planting soil, coffee seed varieties, maintenance, harvesting, until post-harvesting.

\section{REFERENCES}

1. Akiyama, M. et al. (2005). Characterization of Flavor Compounds Released During Grinding of Roasted Robusta Coffee Beans. Food Sci. Technol. Res., 11 (3) 298-307.

2. Harjadi, S. S. 2002. Introduction to Agronomy. Gramedia Pustaka Utama, Jakarta.

3. Hosmer (2011). Applied Logistic Regression. John Wiley \& Sons, Inc: New York.

4. Junaidi, Y. \& M. Yamin (2010). Factors that influence the adoption of diversified agriculture patterns and their relationship with coffee plantation income in South Sumatra. Journal of Human Development, 4, 9 pp.

5. Markoni, May 2012. "Barriers to South Sumatra Coffee Exporters Penetrate Foreign Markets (Case Study of Pt Inti Baru Sejati). Department of Commerce Administration Sriwijaya Polytechnic Negeri. Journal of Business Oration VII th Edition.

6. Ministry of Agriculture. 2017 Coffee. Outlook. Report of the Ministry of Agriculture Plantation Sub-sector, Jakarta: Center for Agricultural Data and Information Systems.

7. Martodireso.2011. Fertilizing Technology Breakthrough in the Era of Organic Agriculture. Kanisius. Prints VII. Yogyakarta. $78 \mathrm{~h}$.

8. Ma'shum M. 2005. Soil Fertility and Fertilization. Mataram University Press. Mataram.

9. Meike, 2012. Productive efficiency of specialty and conventional coffee farmers in Costa Rica: Accounting for heterogeneity in technology. Food Policy, 37 (67-76).

10. Mulyadi. 2014. Accounting Costs. Issue 5. Yogyakarta: UPP STIM YKPN.

11. Najiyati. 2009. Postharvest Cultivation and Handling Coffee. Jakarta.

12. Oktami.2014, Benefits of Rainforest Alliance (Ra) Certification in Developing Sustainable Coffee Farming in Pulau Panggung District, Tanggamus Regency. Department of Agribusiness, Faculty of Agriculture, University of Lampung, JIIA, vol. 2 No. 4

13. Prabowo. 2007. Robusta Coffee Processing. PTPN XII Kebun Malangsar. 